\title{
CALCULATION AND VALIDATION OF ACTUAL EVAPOTRANSPIRATION FROM SATELLITE DERIVED INDICES WITH OBSERVED DATA IN DELINEATED AGRO-CLIMATIC ZONES OF PUNJAB USING REMOTE SENSING AND GIS TECHNIQUES
}

\author{
AMIN, M. ${ }^{1 *}$ - KHAN, M. R. ${ }^{1}$ - BAIG, M. H. A. ${ }^{1}-$ BAIG, I. A. ${ }^{2}$ - IMRAN, M. ${ }^{1}-$ HANIF, M. ${ }^{3}$ \\ ${ }^{I}$ Institute of Geo-Information \& Earth Observation, PMAS Arid Agriculture University, \\ Rawalpindi, Pakistan \\ ${ }^{2}$ Department of Agribusiness and Applied Economics, Muhammad Nawaz Sharif University of \\ Agriculture, Multan, Pakistan \\ ${ }^{3}$ Department of Mathematics and Statistics, PMAS Arid Agriculture University, Rawalpindi, \\ Pakistan \\ *Corresponding author \\ e-mail:m.amin@uaar.edu.pk
}

(Received 24 $4^{\text {th }}$ May 2019; accepted $15^{\text {th }}$ Nov 2019)

\begin{abstract}
Water is the major restrictive constraint for agricultural growth and production. Agro-climate zones refer to the areas with homogenous agro-potential characteristics. The objective of this study is to delineate the agro-climate zones of Punjab, Pakistan and to calculate Actual evapotranspiration (ET ${ }^{\mathrm{a}}$ ) from actual and satellite data. Potential evapotranspiration $\left(\mathrm{ET}^{0}\right)$ was calculated by using climatic normal of 25 years (1990-2015). On the basis of Potential evapotranspiration (ET ${ }^{0}$ ) and Moisture Index, study area was delineated into seven agro-climatic zones. Secondly, ET ${ }^{\mathrm{a}}$ was investigated by adopting a fraction of Normalized difference vegetation index. Landsat 8 data for the year (2016) was used to determine pixel-based vegetation coefficients. Actual ET maps were prepared to analyze spatial variation of ET ${ }^{\mathrm{a}}$ in all zones. Actual ET was determined in mm/day. Daily ET ${ }^{\mathrm{a}}$ values in the months of Jan, Feb, Mar, Apr, May, Jun, Jul, Aug, Sep, Oct and Dec were 1.0, 1.71, 2.70, 3.5, 4.41, 5.01, 5.2, 4.5, 4.37, 3.01, 2.0 and 1.4 $\mathrm{mm}$ respectively. Finally, it was observed that there is a strong relation between both results calculated from satellite data and climatic data of selected crops, i.e. wheat, rice, cotton, sugarcane and maize $\mathrm{R}^{2}=0.96,0.94,0.90,0.98$ and 0.95 respectively. Above results shown that satellite data are widely useful with ground validation for sustainable crop production as well as for policy makers with respect to water conservation.
\end{abstract}

Keywords: agro-climate zones, potential evapotranspiration, moisture index, fraction of vegetation, actual evapotranspiration

\section{Introduction}

Water resources in Pakistan are not sufficient for the proper growth and production of crops. Agriculture is the core of Pakistan's economy; giving about $21-25 \%$ share in Gross Domestic Product (GDP) and serving to about 45-50\% labor force of Pakistan (Bhatti et al., 2009). Pakistan covers about 79.61 million ha, out of which 22 million ha are under cultivation and $75-80 \%$ area is under irrigation while rest of area is rain fed (Iqbal and Ahmad, 2005). About 75-80\% geographical area receives only 250 to $500 \mathrm{~mm}$ rainfall annually, contributing to the arid and semi-arid environment in Pakistan (Baig et al., 2013). Our main objective and primitive need is to calculate ET $^{\mathrm{a}}$ of major crops under available agro-climate and water conditions. The studied rabi 
crops are Wheat, Tomato and kharif crops are Rice, Cotton, Sugarcane, Maize and Citrus Good quality water is the major restrictive constraint for agricultural growth and production (Doorenbos and Kassam, 1979).

Agro-climatic zone is a land unit defined in terms of major climate and growing periods, which is climatically suitable for certain, range of crops and cultivators (Aggarwal, 1993). It requires climatic parameters, i.e. temperature, rainfall, humidity, sunshine hours, wind speed, crop calendar, cropping patterns and land-use information to delineate agro-climatic zones. In Pakistan rainfall mostly occurs in summer due to monsoon winds originating from Indian Ocean especially its north-eastern part. Winter rainfall depends upon western depressions (Ahmad et al., 2015). Pakistan has classified in six Agro-climate zones on the basis of climate and Moisture Index (Chaudhry and Rasul, 2004).

Actual evapotranspiration is the amount of water that is actually removed from a surface through the process of evaporation and transpiration when soil moisture/water source is limited (McKenney and Rosenberg, 1993). Crop evapotranspiration (ET ${ }^{\mathrm{c}}$ ) was estimated by using remote sensing techniques (Singh et al., 2013). Simplified surface energy balance approach was tested to estimate daily Actual evapotranspiration by using Landsat-5 TM data (cropping season, 2007) and ground truth data from Lysimeters (Gowda et al., 2008)

Wheat yield forecasting is analyzed in Punjab province by using satellite data of Landsat 5 TM and MODIS (Dempewolf et al., 2014). Water use for crops was estimated by using simple but robust SSEBop model in United States (Senay et al., 2013). To analyze the impact of land use changes NDVI, $\mathrm{ET}^{0}$, and temperature fraction approach was used with the help of satellite data (Carlson and Arthur, 2000). Vegetation index (VI) based crop coefficients and $\mathrm{ET}^{0}$ calculated from Penman Monteith method was used to calculate actual evapotranspiration of some selected crops by using time series data of Moderate Resolution Imaging Spectroradiometer (MODIS) sensor on Terra satellite (Glenn et al., 2011). Surface energy balance approach was attempted to estimate actual ET from Landsat 5 satellite images and validating it with ground truth data of Oklahoma Mesonet stations to use it for urban area (Liu et al., 2010). Landsat 8 images were used for evaluation of comparison between a remote sensed based reference ET fraction (ETrf) and Mapping EvapoTranspiration at high Resolution with Internalized Calibration (METRIC) model to estimate crop ET coefficients in Idaho, USA. They used 12 images (2000 year) of Landsat to derive NDVI based ETrf (Rafn et al., 2008).

\section{Materials and methods}

The present study was investigated in Punjab, Pakistan lies between $31.17^{\circ} \mathrm{N}$ latitude and $72.70^{\circ} \mathrm{E}$ longitude. It covers an area of about 79,284 $\mathrm{mi}^{2}$ area and it covers about $26 \%$ land area of country. According to the world's temperature zones Pakistan lies in Sub-tropical zone except some northern mountain areas having moderate climate. Overall it falls in arid and semi-arid type of climate. Air temperature varies from $-2{ }^{\circ} \mathrm{C}$ to $45^{\circ} \mathrm{C}$, can reach $51{ }^{\circ} \mathrm{C}$ in summer. Maximum annual temperature ranges between $28{ }^{\circ} \mathrm{C}$ and $32{ }^{\circ} \mathrm{C}$ and minimum annual temperature varies between $15^{\circ} \mathrm{C}$ and $19{ }^{\circ} \mathrm{C}$ in Punjab. Rainy season in Punjab starts from July and runs till September.

Rainfall occurs in summer due to monsoon winds and in winter due to western depressions. Average annual rainfall varies from 270 to $1400 \mathrm{~mm}$. Humidity fluctuates 
from 53 to $64 \%$. Punjab is thickly populated province with an estimated population of about 110.012 million and Lahore is the metropolitan city with the population of 11.1 million according to the census of 2017.

\section{Data requirements}

To accomplish the objectives of the research, climate data from 1990-2015 of 22 weather stations installed in all over Punjab was collected from Pakistan Meteorological Department as shown in Figure 1. The climatic parameters are maximum and minimum temperature, relative humidity, wind speed, sunshine hours and rainfall. Kc values were taken from available literature by (Allen et al., 1998). The Advanced Space borne Thermal Emission and Reflection Radiometer, Global digital elevation model (ASTER GDEM) with spatial resolution of 30 meters was used in the study to show elevation in different parts of Punjab.

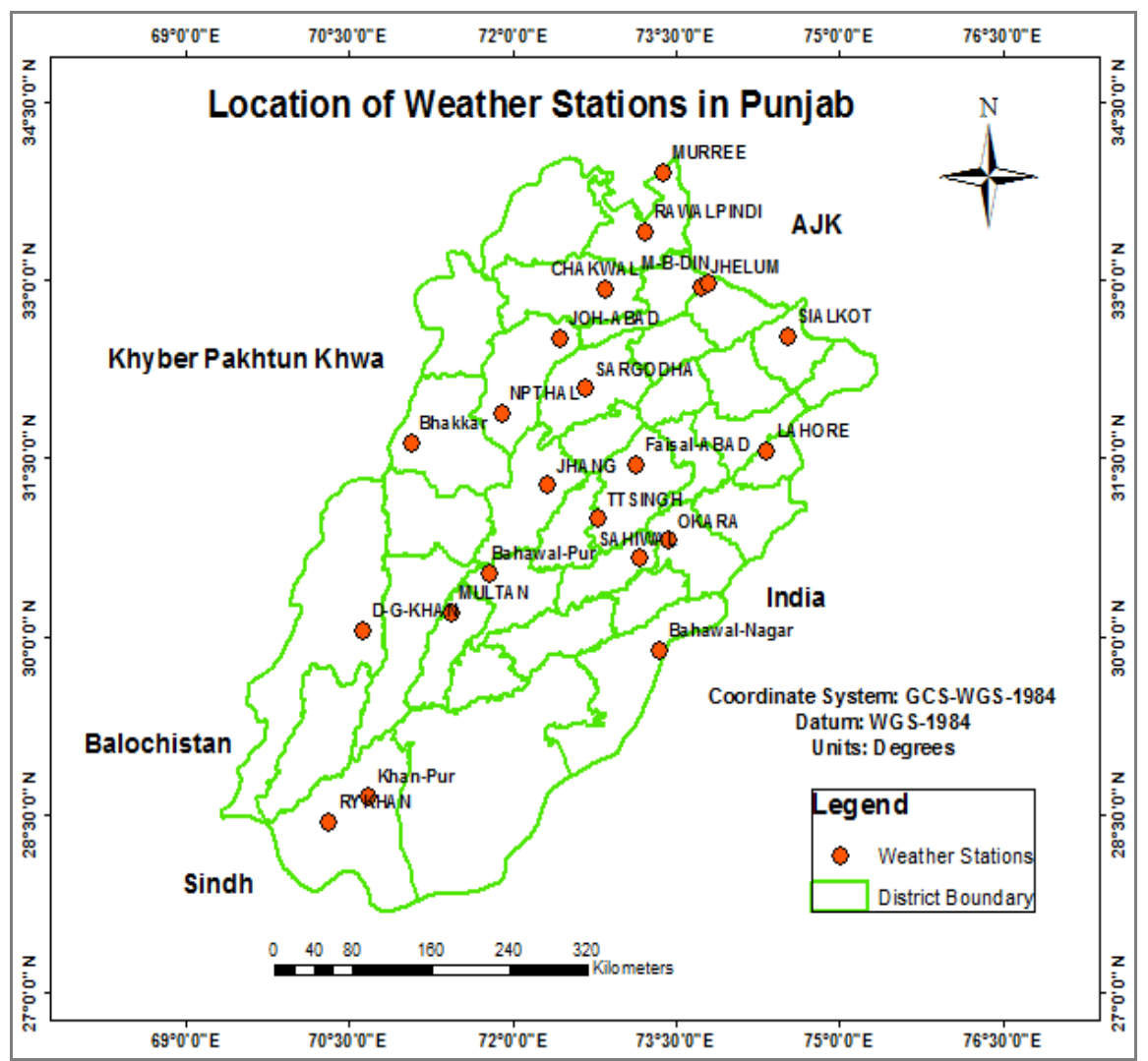

Figure 1. Map showing location of weather stations in Punjab

\section{Satellite data for deriving fraction of vegetation}

Landsat 8 satellite data with less than $10 \%$ cloud cover, were browsed and downloaded for the year 2016 (Rabi-Kharif season), from USGS Earth Explorer website. One limitation was unavailability of images for the month of August, so image for the month of July was used to calculate NDVI fraction. Some images were not fit to the study due to some errors. So, 176 images were selected and utilized in the study. Whole Punjab covers almost 16 images to make one scene/image assuming to be one date image for one date. Figure 2 shows the methodology flow chart of the study. 


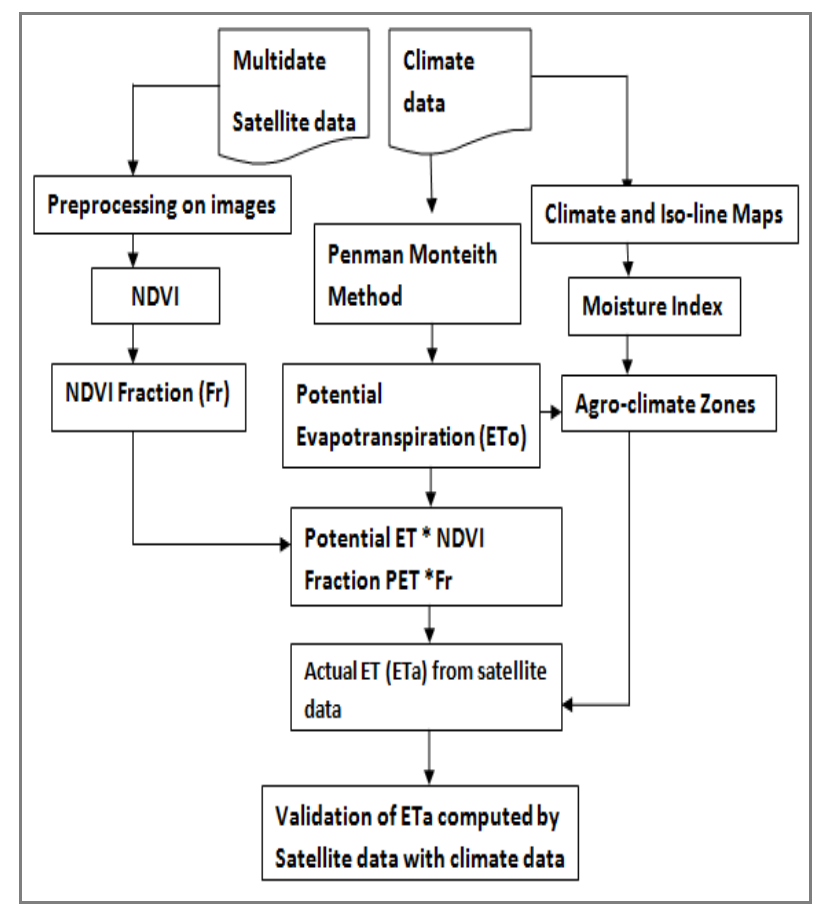

Figure 2. Research methodology flow chart

\section{Potential evapotranspiration (PET)}

Modified Penman Monteith equation was used to estimate ET $^{0}$ by using climatic variables of maximum and minimum temperature, humidity, sunshine hours and wind speed. Additionally, elevation data of weather stations was also used during calculation $\mathrm{ET}^{0}$, mathematical equation for $\mathrm{ET}^{0}$ is given below:

$$
E T_{o}=\frac{0.408 \Delta\left(R_{n}-G\right)+\gamma \frac{900}{T+273} u_{2}\left(e_{s}-e_{a}\right)}{\Delta+\gamma\left(1+0.34 u_{2}\right)}
$$

\section{Thornthwaite moisture index (TMI)}

Thornthwaite Moisture Index (TMI) is a dimensionless index varying from -100 to +100 (Karunarathne et al., 2016). This index was firstly used by (Thornthwaite, 1948). The revised moisture index of Thornthwaite and Marthur (1955) was calculated with the combination of annul potential evapotranspiration and annual rainfall data.

$$
\mathrm{TMI}=\left[\mathrm{P}-\mathrm{ET}^{0} / \mathrm{ET}^{0}\right] \times 100
$$

where: $\mathrm{TMI}=$ moisture index, $\mathrm{P}=$ precipitation, $\mathrm{ET}^{0}=$ potential evapotranspiration. It is an indicator of available soil moisture and water need in any region.

\section{NDVI fraction $(\mathrm{Fr})$}

Vegetation fraction is an indicator for the percentage of vegetation cover (Kharrou et al., 2011) Following formula was used by Gillies et al. (1997) to calculate fraction of vegetation cover $(\mathrm{Fr} / \mathrm{Fov})$ as an indicator of vegetation coefficient in a pixel. 


$$
F \mathrm{r}=\left(\frac{\mathrm{NDVI}-\mathrm{NDVI}_{\mathrm{s}}}{\mathrm{NDVI}_{\mathrm{v}}-\mathrm{NDVI}_{\mathrm{s}}}\right)^{2}
$$

where: $F r=$ fractional vegetation cover, NDVI $=$ NDVI value of image. NDVIs $=$ NDVI value of bare soil, NDVIv = NDVI value of vegetation.

Once the interpolation was done, actual evapotranspiration was estimated by using outputs of potential evapotranspiration $\left(\mathrm{ET}^{0}\right)$ and fraction of vegetation (presuming more ET in intense vegetation) with the help of Raster calculations in GIS environment. Equation for calculating Actual ET is given below:

$$
\text { Actual } \mathrm{ET}=\mathrm{ET}^{0} \times \mathrm{Fr}
$$

where: Actual $\mathrm{ET}=$ actual evapotranspiration, $\mathrm{ET}^{0}=$ potential evapotranspiration, $\mathrm{Fr}=$ fractional vegetation cover.

\section{Results and discussion}

Firstly, potential evapotranspiration $\left(\mathrm{ET}^{0}\right)$ of all weather stations was calculated through Penman Monteith method by using CROPWAT 8.0 software. The maps of all climatic variables, minimum-maximum temperature, humidity, sunshine, wind speed, rainfall and $\mathrm{ET}^{0}$ were prepared in Arc GIS 10.3 While executing interpolation, ninety percent of the values were used whereas remaining ten percent were used as validation data set. The predicted values for the corresponding validation data set were obtained by overlay function in ArcGIS and scatter plots were made to check the accuracy of the interpolation results for validation purpose as shown in Figure 3. There is strong relation of both datasets as $\mathrm{R}^{2}$ is about 0.99 .

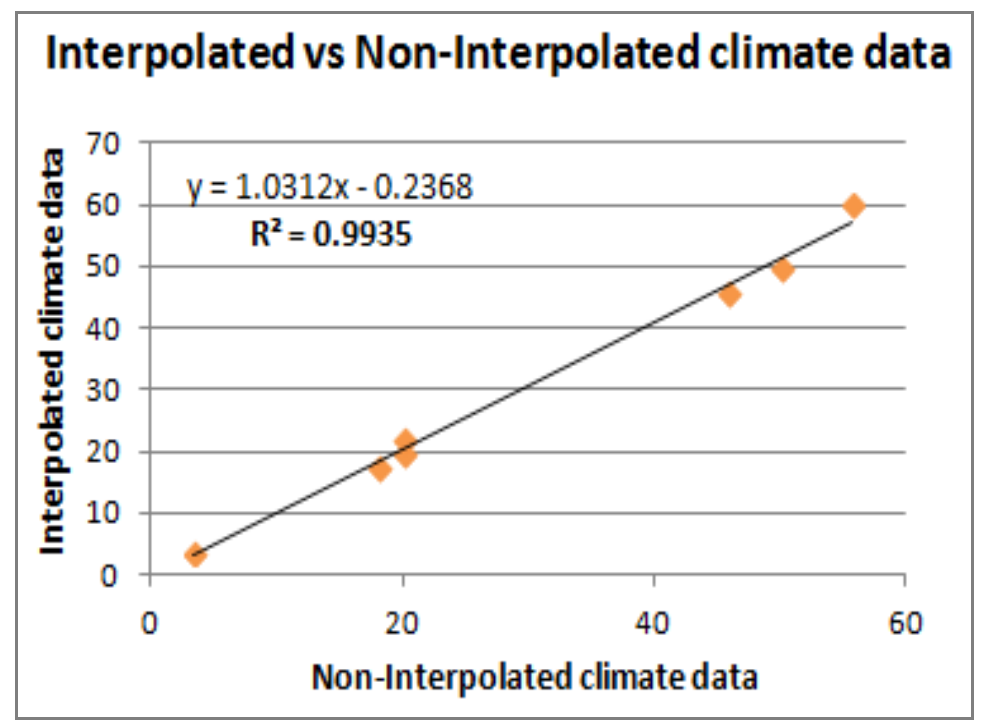

Figure 3. Regression analysis of interpolated vs non-interpolated data

The results of climatic variable shown that temperature of Punjab province increasing trend from upper area (Rawalpindi District) to lower area (D. G Khan and Rajanpur District), Maximum humidity was observed in upper part of Punjab (Murree, 
Rawalpindi and Attock) and minimum humidity was observed in those areas of Punjab where temperature is too high. Maximum sunshine hours were observed in district Rajanpur (8.37) and the minimum sunshine hour in Rawalpindi district (6.71). The maximum wind speed was observed in Muzaffargarh $(2.08 \mathrm{~m} / \mathrm{s})$ and the minimum wind speed was observed in Toba-Tek Singh $(0.31 \mathrm{~m} / \mathrm{s})$. Rainfall variability of Punjab was observed in gradually increasing trend from south to north due to topography of the area as well as severity of monsoon season as shown in Figure 4. About 1000 to $1500 \mathrm{~mm}$ rainfall mapped in upper districts (Rawalpindi, Attock, Jhelum and Chakwal, Sialkot and Gujrat) of Punjab. Lower or southern part of the Punjab have received very low amount of rainfall due to aridity, about 50 to $351 \mathrm{~mm}$ rainfall mapped in Rajanpur and D. G. Khan, Bahawalnagar districts.

Figure $5 a$ showed very low average daily $\mathrm{ET}^{0}$ in upper part of Punjab (Rawalpindi, Attock, Sialkot and Gujrat) while high $\mathrm{ET}^{0}$ was mapped in lower parts of Punjab Bahawalnagar, Rajanpur, Rahim Yar Khan and D. G. Khan districts ranged from $3.0 \mathrm{~mm}$ to $3.19 \mathrm{~mm} /$ day.

\section{Agro-climate zones of Punjab based on climatic parameters}

Contour map of elevation, Iso-line maps of climatic variables were generated in GIS environment. Agro-climatic zones were delineated on the basis of Iso-line/Isopleth maps of climatic parameters.

Moisture index was calculated by using Equation 2. As shown in Table 1, negative values indicate arid climate comprising less precipitation, which cannot fulfill the water need of crops while positive values define moisture and water supply. With the combination of ET0 average annual rainfall maps and Moisture index seven moisture zones were created comprising homogenous characteristics of $\mathrm{ET}^{0}$. Rainfall and moisture supply. In Figure 5b. Agro-climate zone map based on moisture index was prepared in GIS environment by using TMI equation with the help of $\mathrm{ET}^{0}$ and rainfall data. In Zone A with high soil moisture content and Zone B with adequate moisture supply are favorable for crops grown under rain fed conditions.

Table 1. Scaling of moisture index

\begin{tabular}{c|c|c}
\hline Climate type & Moisture index & Zone symbol \\
\hline Hyper-arid & -92.2 to -76.1 & Hyper arid \\
Arid & -76.0 to -63.3 & Arid \\
Semi-arid & -63.2 to -48.1 & Semi-arid \\
Dry sub-humid & -48.0 to -1.0 & Dry sub-humid \\
Moist sub-humid & 1.0 to 20.0 & Moist sub-humid \\
Humid & 20.1 to 100 & Humid \\
Very humid & $>100$ & Very humid \\
\hline
\end{tabular}

Zone $\mathrm{C} 1$ and $\mathrm{C} 2$ having moderate soil moisture, Rabi crops can be grown with slight irrigations but kharif crops require more water for irrigation, as $\mathrm{C} 2$ zone is best for Rice cultivation. The agro-climatic zone map of the study area is shown in Figure 6.

In zone $\mathrm{D}, \mathrm{E}$ crops need water for irrigation during their development stages. These zones consist on arid and semi-arid type of climate with $250-500 \mathrm{~mm}$ annual rainfall. 
Zone $\mathrm{H}$ shows hyper-arid climate, Cotton and Wheat are major crops grown here, require supplement irrigations for their proper nourishment, growth and yield. The results revealed that these agro-climate zones are different from the zones presented by Chaudhry and Rasul (2004) due to the change in climate. They classified Pakistan into six agro-climate zones in 2004. At that time climatic conditions were different from recent. Recent study presents seven agro-climatic zones with different homogenous potentials and constraints.
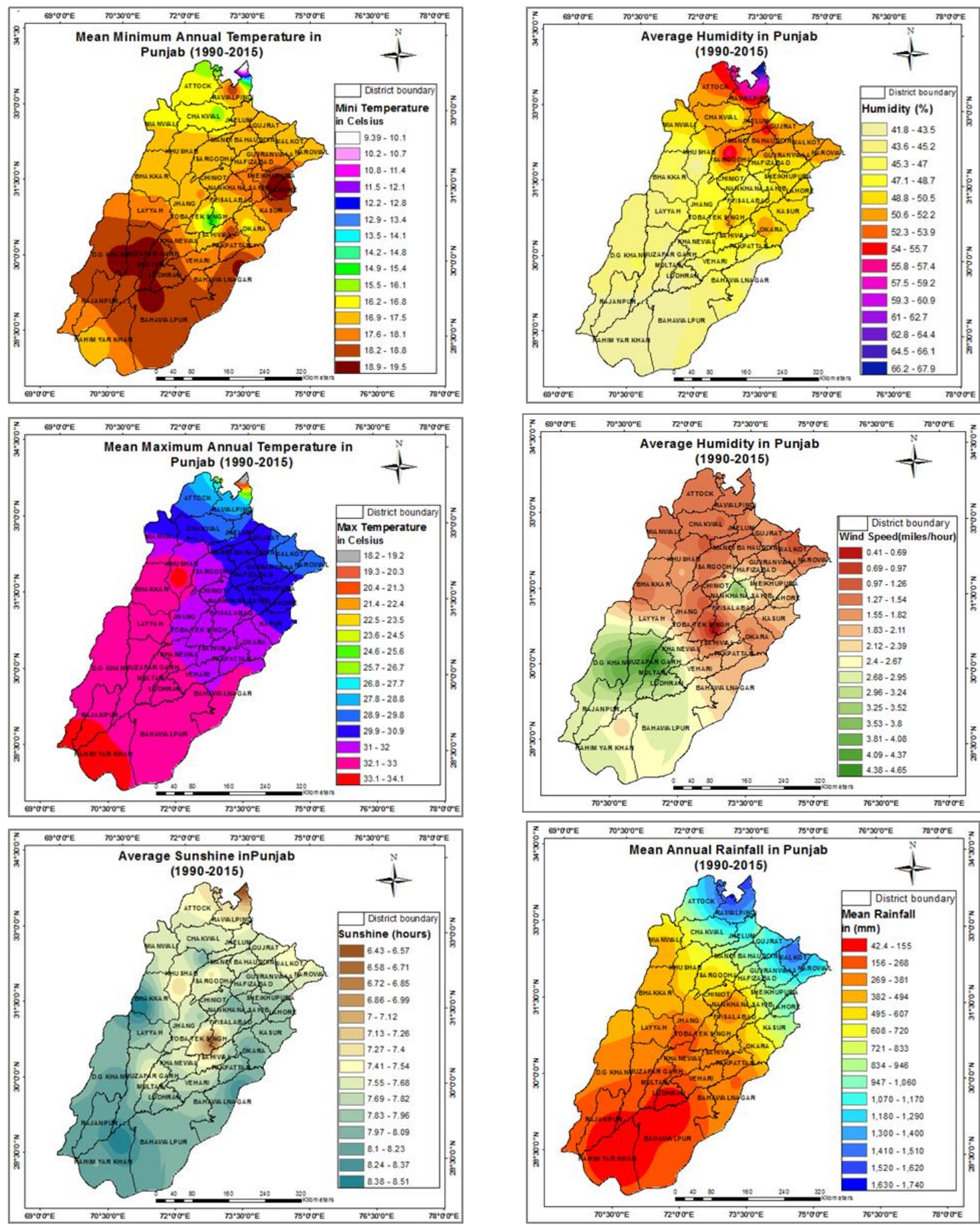

Figure 4. Maps showing mean minimum, maximum temperature $\left({ }^{\circ} \mathrm{C}\right)$, humidity $(\%)$, sunshine (hours), wind speed (mph) and mean annual rainfall $(\mathrm{mm})$ 


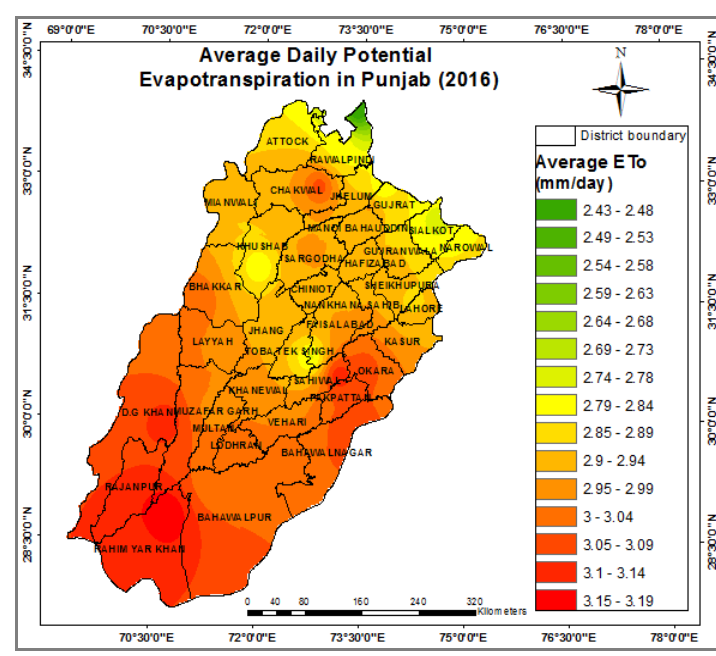

$\mathbf{a}$

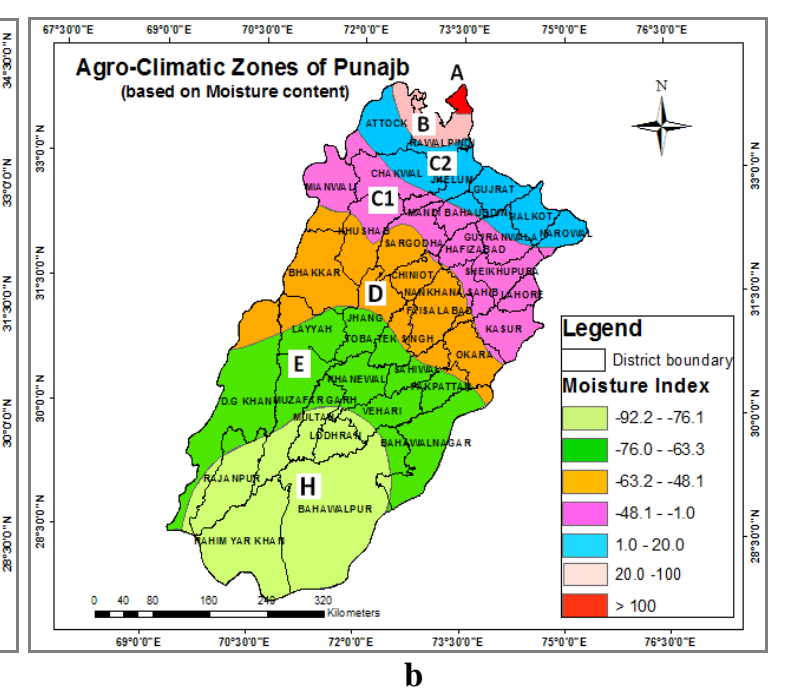

b

Figure 5. (a) Map showing average daily $\mathrm{ET}^{0}(\mathrm{~mm})$ in Punjab. (b) Map showing moisture index

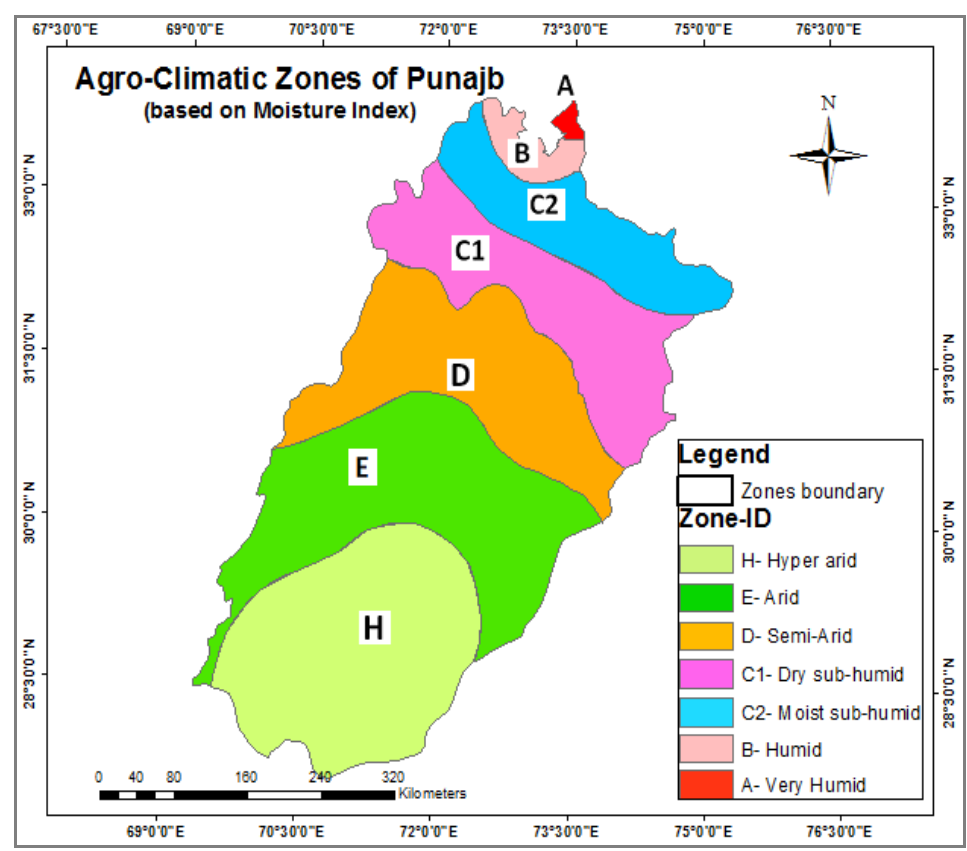

Figure 6. Map showing agro-climatic zones of Punjab

\section{Unsupervised classification of NDVI images}

Crop maps were presented in Figure 7 show most concentrated wheat grown areas are Lahore, Hafizabad, Faisalabad, Gujranwala, Multan and Rawalpindi. It is a widely grown food crop in Pakistan. North-eastern districts, like Sialkot, Narowal, Gujranwala, Hafizabad, Lahore shown highly spatial concentration of rice.

Major Sugarcane growing districts are Sargodha, Lahore, Faisalabad, Toba-Tek Singh and Jhang. Spatial cluster of Cotton is observed in southern Punjab in the districts of Multan, Khanewal, Bahawalnagar, D. G. Khan, Lodhran and Rajanpur. Major maize growing areas are in Gujranwala, Lahore, Hafizabad, Sargodha, Chiniot and Faisalabad districts. 

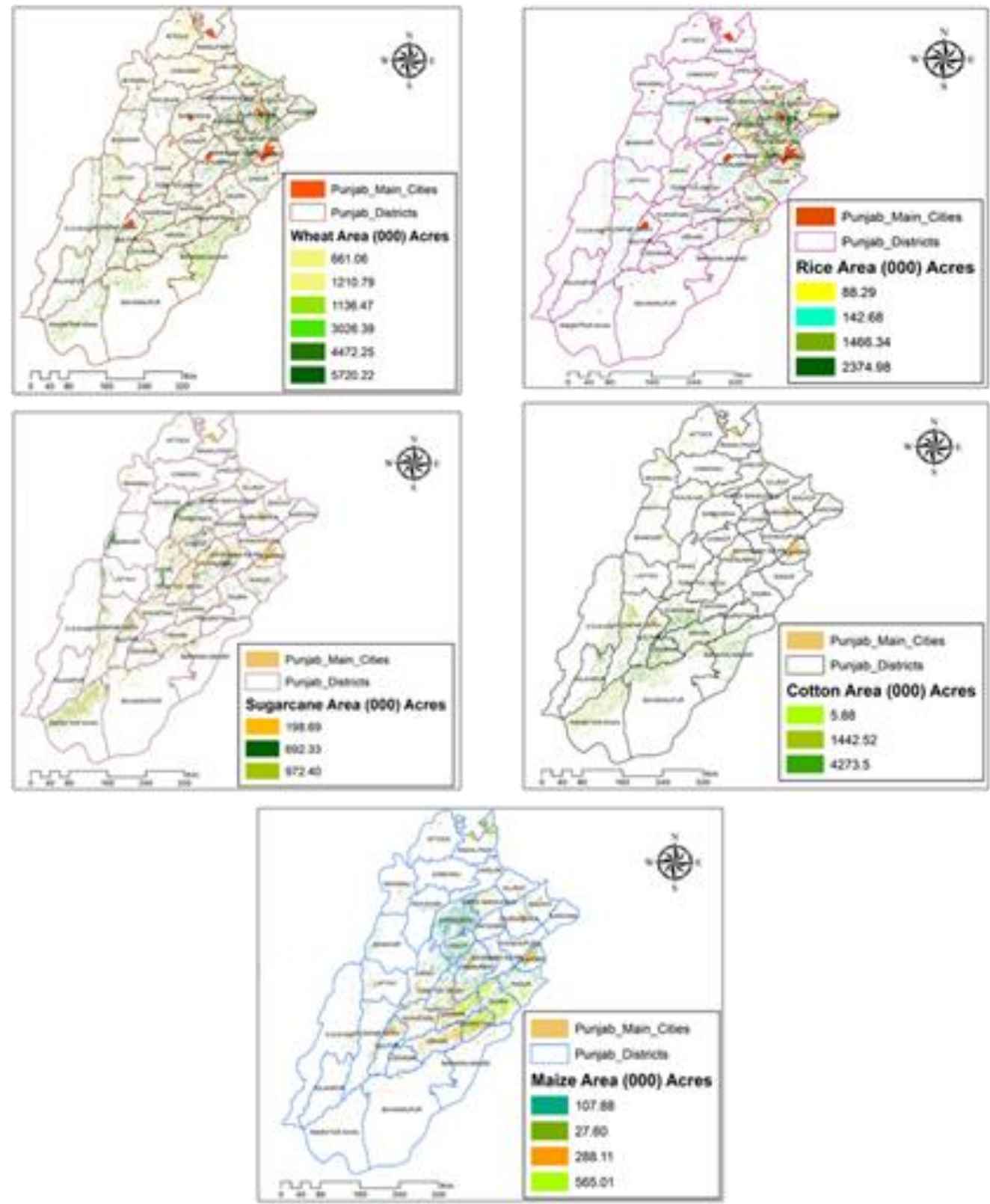

Figure 7. Rabi and kharif crop maps prepared from NDVI classified images

\section{NDVI fraction calculated by satellite images}

NDVI fraction was calculated from NDVI output images and Fr maps were prepared by using Equation 4 in GIS environment. Further, these Fr values were identified for each crop with respect to crop calendar and validated with classified pixels for crops.

\section{$E T^{0}$ calculated by climatic data}

$\mathrm{ET}^{0}$ was calculated by using the Equation 1 with the help of climate data. High $\mathrm{ET}^{0}$ was observed in the months of March, April and May, June, July, August and September for all selected crops. The estimated $\mathrm{ET}^{0}$ results show potential evapotranspiration is high due to hot temperature, long sunshine hours in these months. 
Also wind speed higher in middle and lower part of the study area as compared to upper part. For less $\mathrm{ET}^{0}$ in upper part low temperature is also one reason.

\section{ETa calculated by satellite image}

$\mathrm{ET}^{0}$ maps were generated by using Spline interpolation method within its areal extent of Punjab. By using Equation 4 in raster calculator (ET ${ }^{0}$ maps* $\mathrm{Fr}$ maps) $\mathrm{ET}^{\mathrm{a}}$ maps were produced in Arc GIS 10.3 software. In Figures 8 and 9, PET and ET ${ }^{\mathrm{a}}$ of wheat, rice, cotton, sugarcane and maize crop are shown for 01/Jan, 27/Feb, 30/Mar, 16/Apr, 24/May, 16/Jun, 20/July, 20/Aug, 15/Sep, 15/Oct, 16/Nov, 27/Dec at satellite overpass time (10:00 AM). Also figure Figure 10 shows month wise relation in all agro climatic zones of $\mathrm{ET}^{0}$ and $\mathrm{ET}^{\mathrm{a}}$.

Wheat can be grown in upper districts of Punjab under rainfed conditions. High ET ${ }^{\mathrm{a}}$ was observed in the months of May, June, July, August and September for kharif crops in southern districts of Punjab. Also, high ET ${ }^{\mathrm{a}}$ was observed in month of March, April and may for rabi crops. For sugarcane ET ${ }^{\mathrm{a}}$ was high from month of May to September due annual crop season.

Water demand increases in June and July, because June serves as the hottest month of the year. Overall ET ${ }^{\mathrm{a}}$ in the months of November and December is low due to low temperature and less sunshine hours. Month wise crop seasonal actual evapotranspiration for wheat, rice, cotton, sugarcane and maize is 333.6, 758.4, 654, 1019.7 and $1172.4 \mathrm{~mm}$, respectively (Tables 2 and 3).

Table 2. Daily ET ${ }^{a}(\mathrm{~mm})$ of all selected crops by using satellite data

\begin{tabular}{|c|c|c|c|c|c|c|c|c|c|c|c|c|}
\hline \multirow{2}{*}{ Crops } & \multicolumn{12}{|c|}{ Daily ETa of all selected crops ( $\mathrm{mm} /$ day) by using satellite data } \\
\hline & Jan 01 & Feb 27 & Mar 30 & Apr 16 & May 24 & Jun 15 & Jul 20 & Aug 20 & Sep 15 & Oct 15 & Nov 16 & Dec 27 \\
\hline Wheat & 0.82 & 1.37 & 2.72 & 2.70 & 2.05 & & & & & & 0.68 & 0.78 \\
\hline Rice & & & & & 3.57 & 4.88 & 4.80 & 4.45 & 4.37 & 2.04 & 1.17 & \\
\hline Cotton & & & & & 1.74 & 3.85 & 5.29 & 4.41 & 4.30 & 1.59 & 0.62 & \\
\hline Sugarcane & 0.57 & 0.91 & 1.80 & 2.69 & 4.04 & 4.83 & 5.27 & 4.58 & 4.32 & 2.66 & 1.56 & 0.76 \\
\hline Maize & & & & & & & 0.66 & 2.86 & 4.08 & 1.77 & 0.99 & \\
\hline
\end{tabular}

Table 3. Month wise crop Seasonal ET ${ }^{a}(\mathrm{~mm})$ of all selected crops by using satellite data

\begin{tabular}{|c|c|c|c|c|c|c|c|c|c|c|c|c|c|}
\hline \multirow{2}{*}{ Crops } & \multicolumn{13}{|c|}{ Daily ETa of all selected crops (mm/month) by using satellite data } \\
\hline & Jan & Feb & Mar & Apr & May & Jun & Jul & Aug & Sep & Oct & Nov & Dec & Annual ETa (mm) \\
\hline Wheat & 24.6 & 41.1 & 81.6 & 81 & 61.5 & & & & & & 20.4 & 23.4 & 333.6 \\
\hline Rice & & & & & 107.1 & 146.4 & 144 & 133.5 & 131.1 & 61.2 & 35.1 & & 758.4 \\
\hline Cotton & & & & & 52.2 & 115.5 & 158.7 & 132.3 & 129 & 47.7 & 18.6 & & 654 \\
\hline Sugarcane & 17.1 & 27.3 & 54 & 80.7 & 121.2 & 144.9 & 158.1 & 137.4 & 129.6 & 79.8 & 46.8 & 22.8 & 1019.7 \\
\hline Maize & & & & & & & 19.8 & 85.8 & 122.4 & 53.4 & 891 & & 1172.4 \\
\hline
\end{tabular}

\section{Validation of ETa computed by both datasets}

The validation of actual ET at pixel basis is a major issue, so that $\mathrm{ET}^{\mathrm{a}}$ from climate data is also used for comparison. Results showed actual evapotranspiration calculated from satellite data; provide accurate results with minor deviation from satellite data. ET ${ }^{\mathrm{a}}$ 
values computed from satellite data were validated with ETa computed from climate data by a statistical analysis in MS Excel software. Coefficient values of wheat, rice, cotton, sugarcane, maize are $\mathrm{R}^{2}=0.96,0.94,0.90,0.98,0.95$ respectively (Fig. 11). These coefficient values show strong relationship of ET ${ }^{\mathrm{a}}$ estimated from both data sets.

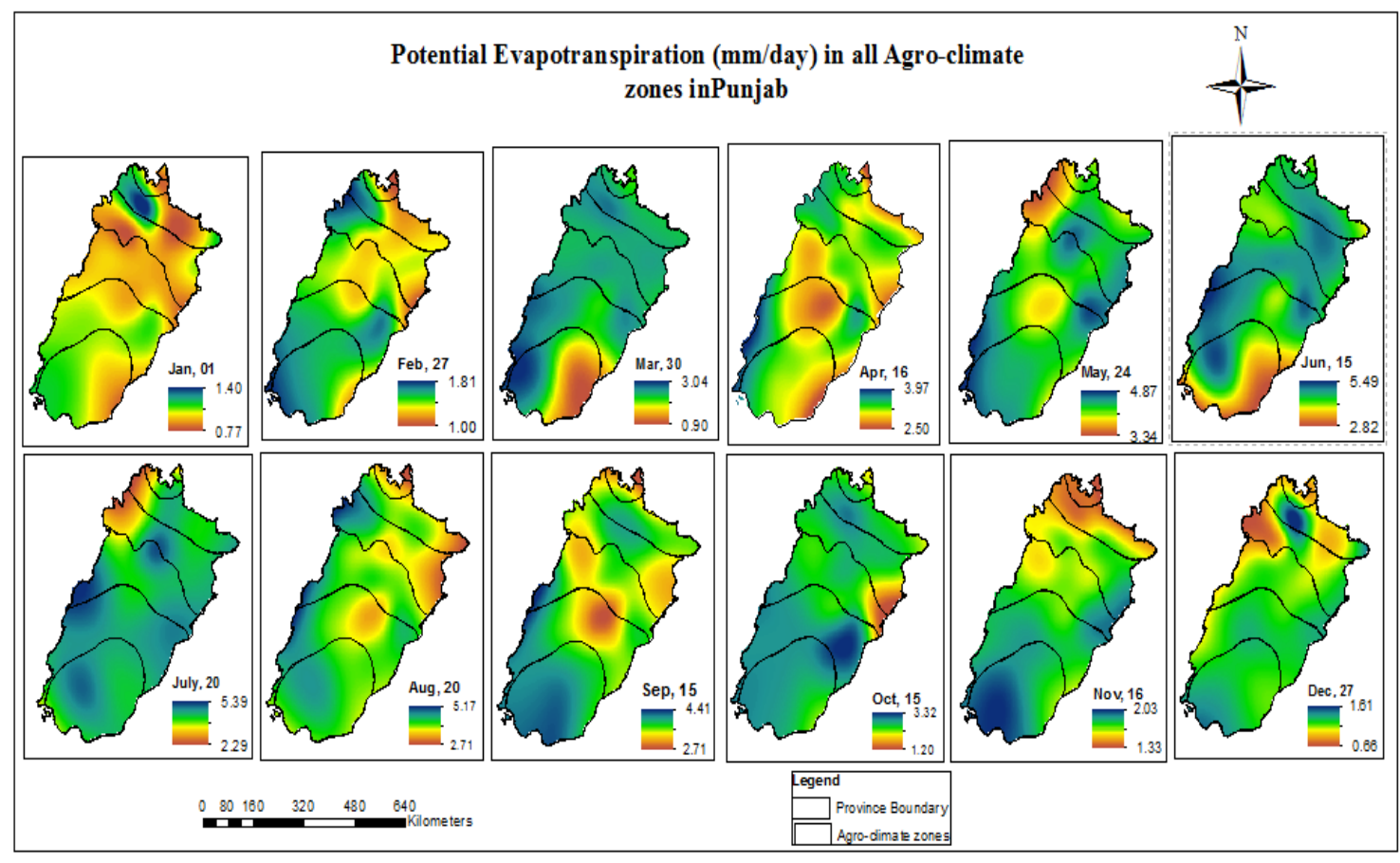

Figure 8. Daily $E T^{0}$ maps for all the months

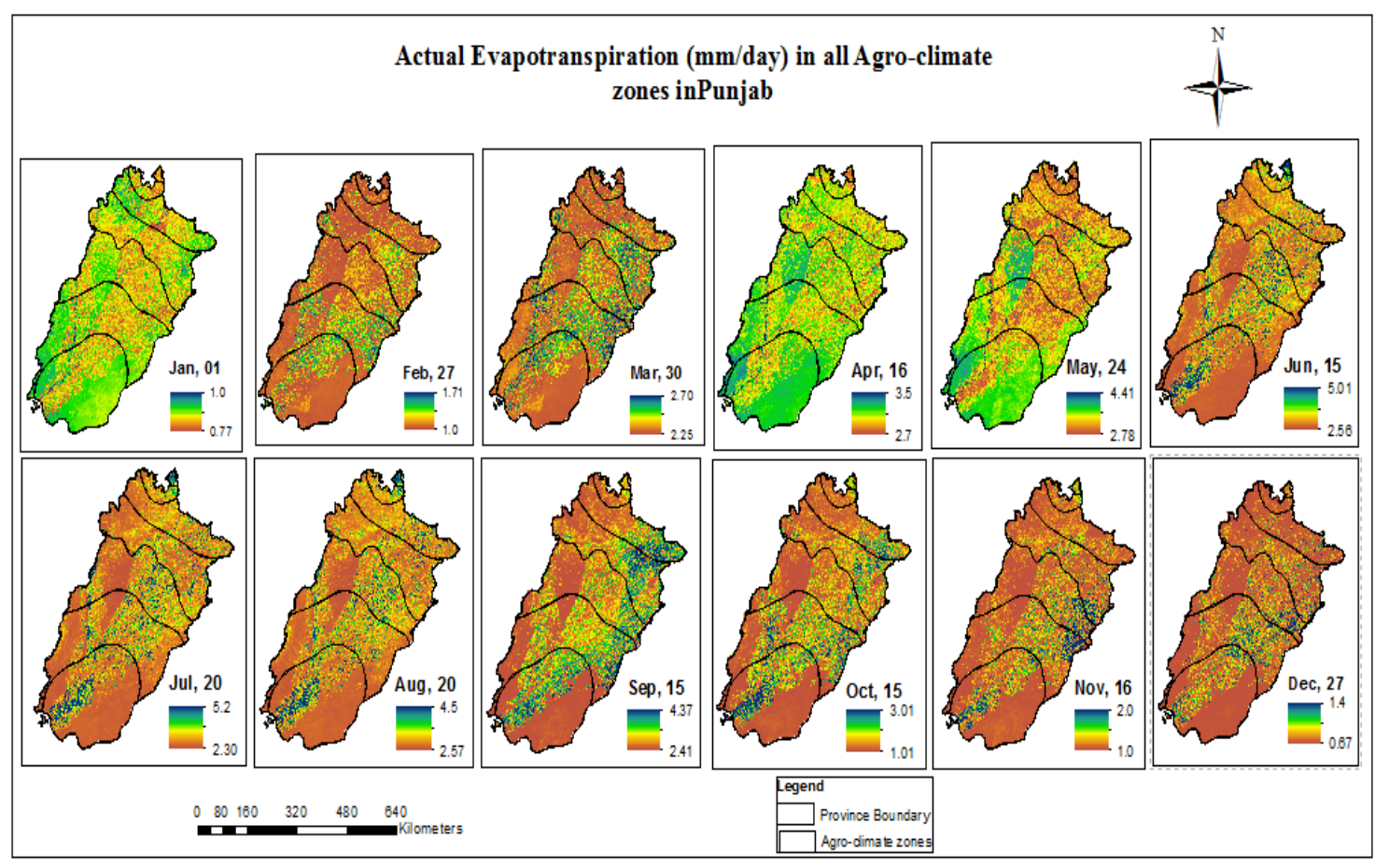

Figure 9. Daily ET ${ }^{a}$ maps for all the months 


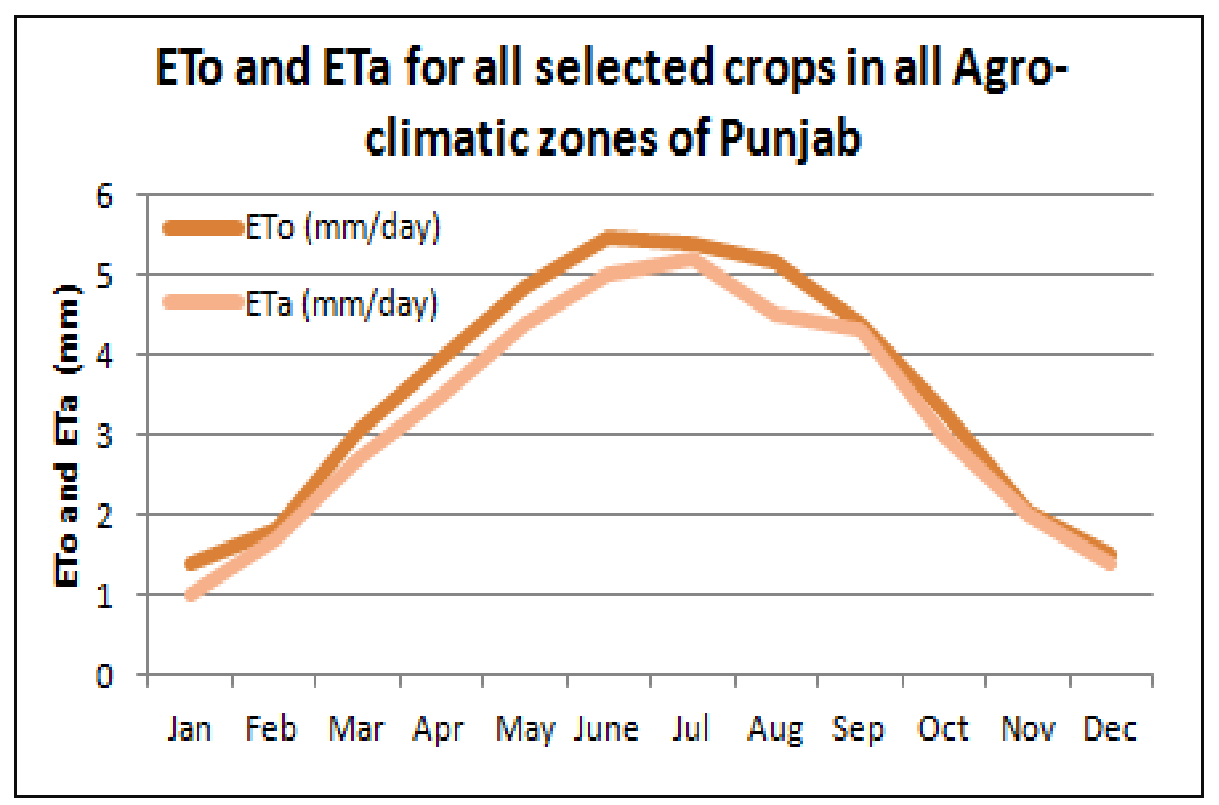

Figure 10. Month wise comparison of $E T^{0}$ and $E T^{a}$
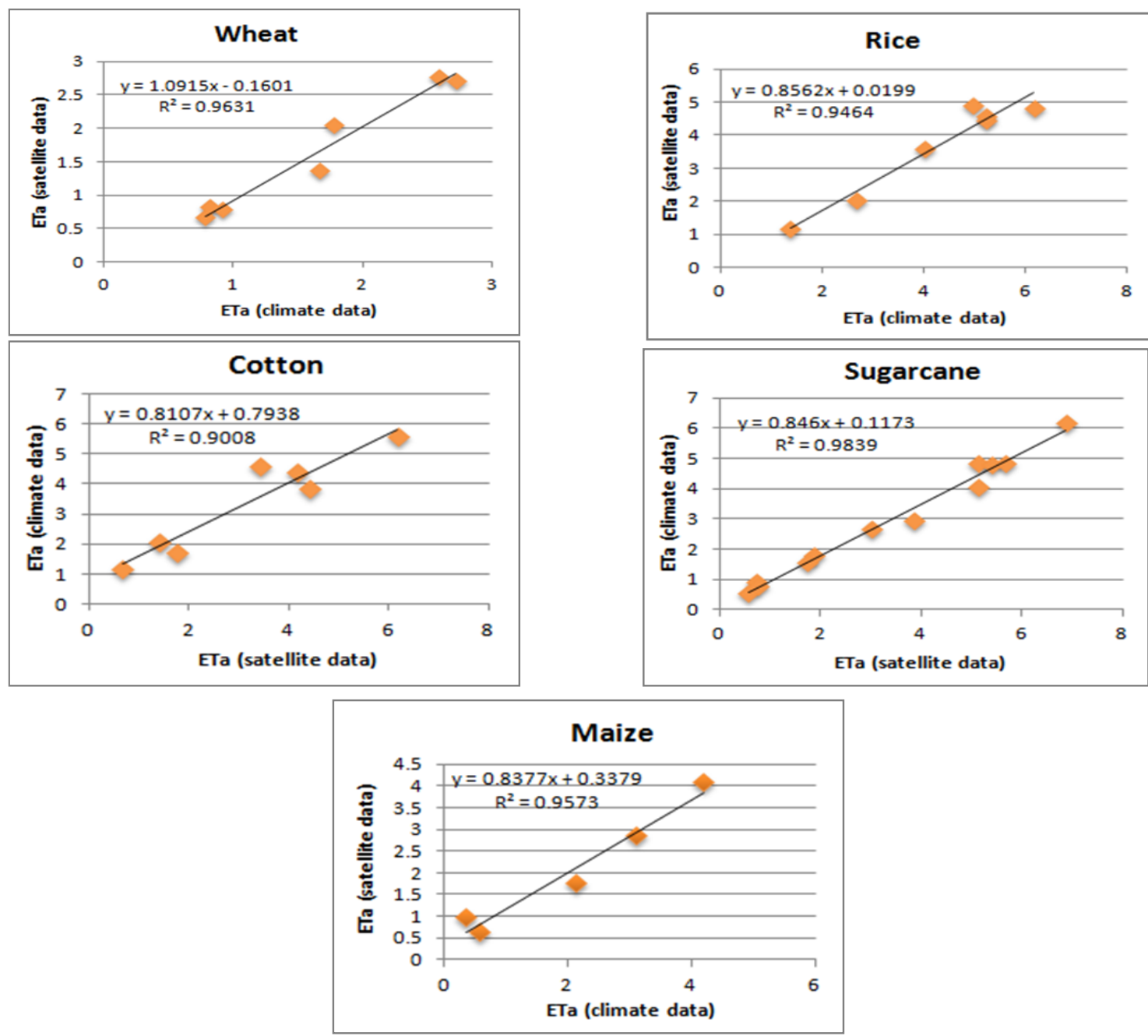

Figure 11. Statistical relationship of ET ${ }^{a}$ computed from both datasets 


\section{Conclusion}

The research findings show NDVI fraction approach gives the best result with minimum degree of variation of spatial distribution of ET ${ }^{\mathrm{a}}$ over large area. It serves as best method to apply at regional level in Pakistan when dealing with multi-date satellite data. Wheat, and Maize can be grown under rainfall conditions with minimum irrigations but Rice, Cotton and Sugarcane, require supplement irrigations throughout their growth. More water is required in zone I, II and III (southern zones) in the months of May, June, July, August and September as compared to other zones. Strong positive coefficient values show Remote sensing based ET ${ }^{\mathrm{a}}$ can provide helpful and in time need of water for crops. Such type of studies should be made in other provinces of Pakistan for better use of water resources and sustainable agriculture.

Acknowledgements. Thanks to research collaborators and for institutional support of "Institute of GeoInformation \& Earth Observation, PMAS Arid Agriculture University Rawalpindi".

\section{REFERENCES}

[1] Aggarwal, P. (1993): Agro-Ecological Zoning Using Crop Growth Simulation Models: Characterization of Wheat Environments of India. - In: Penning de Vries, F. et al. (eds.) Systems Approaches for Agricultural Development. Springer, Dordrecht, pp. 97-109.

[2] Ahmad, A., Ashfaq, M., Rasul, G., Wajid, S. A., Khaliq, T., Rasul, F., ... Ahmad Baig, I. (2015): Impact of Climate Change on the Rice-Wheat Cropping System of Pakistan. - In: Rosenzweig, C., Hillel, D. (eds.) Handbook of Climate Change and Agroecosystems: The Agricultural Model Intercomparison and Improvement Project Integrated Crop and Economic Assessments, Part 2. World Scientific, Singapore, pp. 219-258.

[3] Allen, R., Pereira, L., Raes, D., Smith, M. (1998): Guidelines for Computing Crop Water Requirements. FAO Irrigation and Drainage Paper 56. - FAO-Food and Agriculture Organisation of the United Nations, Rome. http://www.fao.org/docrep.

[4] Baig, M. B., Shahid, S. A., Straquadine, G. S. (2013): Making rainfed agriculture sustainable through environmental friendly technologies in Pakistan: a review. International Soil and Water Conservation Research 1(2): 36-52.

[5] Bhatti, A. M., Suttinon, P., Nasu, S. (2009): Agriculture water demand management in Pakistan: a review and perspective. - Society for Social Management Systems 9(172): 17.

[6] Carlson, T. N., Arthur, S. T. (2000): The impact of land use - land cover changes due to urbanization on surface microclimate and hydrology: a satellite perspective. - Global and Planetary Change 25(1-2): 49-65.

[7] Chaudhry, Q., Rasul, G. (2004): Agroclimatic classification of Pakistan. - Science Vision 9(3-4): 59-66.

[8] Dempewolf, J., Adusei, B., Becker-Reshef, I., Hansen, M., Potapov, P., Khan, A., Barker, B. (2014): Wheat yield forecasting for Punjab Province from vegetation index time series and historic crop statistics. - Remote Sensing 6(10): 9653-9675.

[9] Doorenbos, J., and Kassam, A. (1979): Yield Response to Water. - FAO Irrigation and Drainage Paper 33. FAO, Rome.

[10] Gillies, R., Kustas, W., Humes, K. (1997): A verification of the 'triangle' method for obtaining surface soil water content and energy fluxes from remote measurements of the Normalized Difference Vegetation Index (NDVI) and surface e. - International Journal of Remote Sensing 18(15): 3145-3166. 
[11] Glenn, E. P., Neale, C. M., Hunsaker, D. J., Nagler, P. L. (2011): Vegetation index-based crop coefficients to estimate evapotranspiration by remote sensing in agricultural and natural ecosystems. - Hydrological Processes 25(26): 4050-4062.

[12] Gowda, P. H., Senay, G. B., Colaizzi, P. D., Howell, T. A. (2008): Simplified surface energy balance (SSEB) approach for estimating actual ET: an evaluation with lysimeter data. - Paper presented at the 2008 Providence, Rhode Island, June 29-July 2, 2008.

[13] Iqbal, M., Ahmad, M. (2005): Science \& Technology Based Agriculture Vision of Pakistan and Prospects of Growth. - Paper presented at the Proceedings of the 20th Annual General Meeting Pakistan Society of Development Economics, Islamabad. Pakistan Institute of Development Economic (PIDE), Islamabad, Pakistan.

[14] Karunarathne, A., Gad, E., Disfani, M., Sivanerupan, S., Wilson, J. (2016): Review of calculation procedures of Thornthwaite Moisture Index and its impact on footing design. - Australian Geomechanics 51(1): 85-95.

[15] Kharrou, M. H., Er-Raki, S., Chehbouni, A., Duchemin, B., Simonneaux, V., LePage, M., ... Jarlan, L. (2011): Water use efficiency and yield of winter wheat under different irrigation regimes in a semi-arid region. - Agricultural Sciences in China 2(3): 273-282.

[16] Liu, W., Hong, Y., Khan, S. I., Huang, M., Vieux, B., Caliskan, S., Grout, T. (2010): Actual evapotranspiration estimation for different land use and land cover in urban regions using Landsat 5 data. - Journal of Applied Remote Sensing 4(1): 041873.

[17] McKenney, M. S., Rosenberg, N. J. (1993): Sensitivity of some potential evapotranspiration estimation methods to climate change. - Agricultural and Forest Meteorology 64(1-2): 81-110.

[18] Rafn, E. B., Contor, B., Ames, D. P. (2008): Evaluation of a method for estimating irrigated crop-evapotranspiration coefficients from remotely sensed data in Idaho. Journal of Irrigation and Drainage Engineering 134(6): 722-729.

[19] Senay, G. B., Bohms, S., Singh, R. K., Gowda, P. H., Velpuri, N. M., Alemu, H., Verdin, J. P. (2013): Operational evapotranspiration mapping using remote sensing and weather datasets: a new parameterization for the SSEB approach. - JAWRA Journal of the American Water Resources Association 49(3): 577-591.

[20] Singh, S., Dutta, S., Dharaiya, N. (2013): Estimation of crop evapotranspiration of cotton using remote sensing technique. - Int. J. Environ. Eng. Manag. 4: 523-528.

[21] Thornthwaite, C. W. (1948): An approach toward a rational classification of climate. Geographical Review 38(1): 55-94. 